\title{
Biochemical Analysis of the Bacillus subtilis 1604 Spore Germination Response
}

\author{
By PADMAVATHY VENKATASUBRAMANIAN AND \\ KEITH JOHNSTONE* \\ Department of Botany, University of Cambridge, Downing Street, Cambridge CB2 3EA, UK
}

(Received 22 December 1988; revised 22 May 1989; accepted 23 June 1989)

\begin{abstract}
Germination at $37^{\circ} \mathrm{C}$ of spores of Bacillus subtilis 1604 in the L-alanine and potassium phosphate (ALA) and the glucose, fructose, L-asparagine, potassium chloride (GFAK) germinant systems was triggered following heat activation at $70^{\circ} \mathrm{C}$ for $1 \mathrm{~h}$. In these conditions, $50 \%$ of the spore population became committed to germinate after exposure for $10 \mathrm{~min}$ and $14 \mathrm{~min}$ to ALA and GFAK, respectively, at which time $38 \%$ and $30 \%$ losses of $\mathrm{OD}_{600}$ had taken place. Dipicolinic acid (DPA) release, loss of heat resistance and release of soluble hexosamine-containing fragments occurred after commitment and were closely associated with loss of refractility in both the ALA and GFAK pathways. Net ATP synthesis could not be detected until 3-4 min after initiation of germination in both ALA and GFAK, by which time $>20 \%$ of the spore population was committed to germinate. The ALA and GFAK germination pathways were $>99 \%$ inhibited by 3 and $1 \mathrm{mM}-\mathrm{HgCl}_{2}$, respectively, as measured by $\mathrm{OD}_{600}$ loss. Reversible post-commitment $\mathrm{HgCl}_{2}$-sensitive sites were present in the ALA and GFAK pathways which were $50 \%$ inhibited by $0.125 \mathrm{mM}$ and $0.05 \mathrm{mM}-\mathrm{HgCl}_{2}$, respectively. A pre-commitment $\mathrm{HgCl}_{2}-$ sensitive site was identified in the ALA pathway which was $55 \%$ inhibited by $6 \mathrm{mM}-\mathrm{HgCl}_{2}$. At $3 \mathrm{mM}-\mathrm{HgCl}_{2}, 70 \%$ of the spore population became committed to germinate in the ALA pathway, whereas $<5 \% \mathrm{OD}_{600}$ loss occurred. In this system, loss of heat resistance was associated with commitment, whereas $\mathrm{OD}_{600}$ loss and DPA release were identified as post-commitment events. The ALA and GFAK pathways were insensitive to a variety of metabolic inhibitors. Protease inhibitors had different effects on the ALA and GFAK pathways: phenylmethanesulphonyl fluoride (PMSF) solely inhibited ALA germination at a pre-commitment site and had little effect on GFAK germination, whereas $N^{\alpha}$-p-tosyl-L-arginine methyl ester (TAME) inhibited both the ALA and GFAK pathways at pre- and post-commitment sites. These results are discussed in relation to a recently proposed model for the triggering of Bacillus megaterium $\mathrm{KM}$ spore germination.
\end{abstract}

\section{INTRODUCTION}

In spite of their extreme dormancy, bacterial spores retain an alert sensory mechanism capable of responding within minutes to the presence of spore-specific germinants (Gould 1969). This response is initiated by the interaction of a germinant receptor protein with the germinants, which triggers an irreversible commitment reaction and the ensueing loss of dormant spore properties (Stewart et al., 1981). Despite intensive study, the molecular basis of the germination triggering and commitment reactions remains to be elucidated (Setlow, 1981).

\footnotetext{
Abbreviations: ALA, L-alanine $+\mathrm{K}^{+}$; GFAK, D-glucose + D-fructose + L-asparagine + KCl; DPA, pyridine2,6-dicarboxylic (dipicolinic) acid; GSLE, germination-specific cortex-lytic enzyme; NEM, $N$-ethylmaleimide; PMSF, phenylmethanesulphonyl fluoride; TAME, $N^{\alpha}$-p-tosyl-L-arginine methyl ester; TLCK, $N^{\alpha}-p$-tosyl-Llysylchloromethane.
} 
The biochemistry of spore germination has been most comprehensively studied using spores of Bacillus megaterium KM, which possess a single L-alanine-dependent pathway (Stewart et al., 1981). In spores of this organism, the germination triggering and commitment reactions take place in the absence of both germinant and germinant-stimulated metabolism (Scott \& Ellar, $1978 a, b)$. The earliest detected enzyme-catalysed germination event is selective hydrolysis of the cortical peptidoglycan (Johnstone \& Ellar, 1982; Johnstone et al., 1982). Based on inhibitor studies, a model of germination triggering has recently been proposed (Foster \& Johnstone, 1986) in which the germinant receptor protein has L-alanine dependent proteolytic activity, cleaving the pro-form of a germination-specific cortex-lytic enzyme (GSLE) to yield active GSLE. The ensueing limited cortex hydrolysis allows core water uptake and the onset of all subsequent germination events. In this model $\mathrm{HgCl}_{2}$ acts as a germination inhibitor at both preand post-commitment sites, whereas the protease inhibitor PMSF inhibits germination solely at a pre-commitment site (Foster \& Johnstone, 1986). Active GSLE has been purified from spores of $B$. megaterium $\mathrm{KM}$ and has biochemical properties consistent with a functional role in the germination response (Foster \& Johnstone, 1987). It has recently been demonstrated that proteolytic activation of GSLE from a pro-form bound to the cortical peptidoglycan occurs during commitment of spores of $B$. megaterium KM (Foster \& Johnstone, 1988).

In contrast, Bacillus subtilis spore germination has been most extensively studied by genetical methods (Moir \& Smith, 1985). It can be triggered by L-alanine/potassium phosphate (ALA) or by glucose/fructose/L-asparagine/potassium chloride (GFAK) (Wax \& Freese, 1968). Germination mutants have been isolated from $B$. subtilis which are (i) deficient in their ALA response, but normal in their GFAK response (ger A and gerC: Moir et al., 1979; Sammons et al., 1981), (ii) deficient in their GFAK response, but normal in their ALA response (gerB and gerK: Moir et al., 1979; Irie et al., 1982), and (iii) deficient in both their ALA and GFAK responses at an intermediate stage in germination (gerD, gerE, ger F, gerH, and gerJ: Moir et al., 1979; Piggot et $a l ., 1981)$. These observations suggest that separate germinant receptors exist in this organism which converge to form a common germination pathway (Piggot et al., 1981). The functional roles of the ger gene products in the $B$. subtilis spore germination response remain to be established. The dependency of $B$. subtilis spore germination on the concentration of components of ALA (Sammons et al., 1981) and GFAK (Wax \& Freese, 1968) has been previously examined.

The present paper describes biochemical experiments carried out to further characterize the $B$. subtilis spore germination pathways using approaches similar to those previously used for spores of $B$. megaterium $\mathrm{KM}$. It is demonstrated that germinant-dependent proteolytic activity is associated with commitment in the ALA response and that there are common post-commitment events in the germination pathways of $B$. subtilis.

\section{METHODS}

Spore formation and germination. All experiments were carried out using spores of Bacillus subtilis 1604 , a $\operatorname{trpC}$ derivative of $B$. subtilis 168 (Moir et al., 1979) which was kindly provided by Dr A. Moir, University of Sheffield, UK. Spores were prepared at $37^{\circ} \mathrm{C}$ as described previously for B. megaterium KM (Stewart et al., 1981) and stored at $10 \mathrm{mg} \mathrm{ml}^{-1}$ in distilled water at $-20^{\circ} \mathrm{C}$. Dormant spore preparations contained no detectable vegetative cells and had $>98 \%$ phase-bright spores when examined by phase-contrast microscopy. Immediately prior to germination, spore suspensions $\left(10 \mathrm{mg}\right.$ dry weight $\left.\mathrm{ml}^{-1}\right)$ were heat-activated at $70^{\circ} \mathrm{C}$ for $60 \mathrm{~min}$, unless otherwise stated, and cooled on ice. Germination of spore suspensions ( $50 \mu \mathrm{g}$ dry wt $\mathrm{ml}^{-1}$ unless otherwise stated) was initiated at $37^{\circ} \mathrm{C}$, except where otherwise stated, either in $50 \mathrm{~mm}$-potassium phosphate buffer, $\mathrm{pH} 7.4$, by the addition of $1 \mathrm{mM}$ (final concentration) L-alanine (ALA) or in $50 \mathrm{~mm}$-Tris/ $\mathrm{HCl}$ buffer, $\mathrm{pH} 7 \cdot 5$, by the addition of final concentrations of $30 \mathrm{~mm}$ - L-asparagine, $5.6 \mathrm{~mm}$ - $\beta$-D-glucose, $5.6 \mathrm{~mm}$ - $\beta$-D-fructose and $67 \mathrm{mM}-\mathrm{KCl}$ (GFAK).

The extent of germination was determined as the percentage of the control loss in $\mathrm{OD}_{600}$ of spore suspensions (Scott \& Ellar 1978 a) after $60 \mathrm{~min}$ or $80 \mathrm{~min}$, for the ALA and GFAK systems respectively, in a Pye Unicam SP8200 UV-VIS spectrometer, fitted with a constant-temperature cell-holder. The rate of germination was measured as the maximum rate of loss of $\mathrm{OD}_{600}$ per minute divided by the initial $\mathrm{OD}_{600}\left(\mathrm{~V}_{\max }\right.$; Bright \& Johnstone, 1987). The extent of germination was confirmed at the end of each experiment by determining the ratio of phase-bright to phase-dark spores. In all experiments the percentage of spores which became phase-dark correlated with the percentage loss of $\mathrm{OD}_{600}$. Where indicated, inhibitors were added at the stated concentrations to spore 
suspensions at $37^{\circ} \mathrm{C} 15 \mathrm{~min}$ prior to the addition of germinants. The control germination response for inhibition studies represents that of untreated spores, for which $50-60 \%$ loss of initial OD $_{600}$ was observed.

Measurement of early germination events. Commitment was measured using the method of Stewart et al. (1981) modified as follows. Heat-shocked spores were germinated in Corex tubes, at $5 \mathrm{mg} \mathrm{ml}^{-1}$, in ALA or GFAK with constant stirring and, at intervals after addition of germinants, samples were diluted into cuvettes at $37^{\circ} \mathrm{C}$ containing $10 \mathrm{mM}$-D-alanine or $300 \mathrm{~mm}$-D-asparagine, for the ALA and GFAK systems respectively. Control experiments demonstrated no significant change in the rate of $\mathrm{OD}_{600}$ loss when spores were germinated between $50 \mu \mathrm{g} \mathrm{ml}^{-1}$ and $5 \mathrm{mg} \mathrm{ml}^{-1}$. The spores were then allowed to germinate for total periods of $60 \mathrm{~min}$ and $80 \mathrm{~min}$ in the ALA and GFAK systems, respectively, in order to allow the committed spores to germinate. Commitment was determined in each sample at the end of the germination period as the percentage of $\mathrm{OD}_{600}$ loss compared with that in the control exposed to ALA or GFAK for $60 \mathrm{~min}$ or $80 \mathrm{~min}$, respectively. No commitment was observed in the time zero control, in which spores were diluted tenfold into $10 \mathrm{mM}-\mathrm{D}$-alanine (in the ALA system) or into $300 \mathrm{mM}$-D-asparagine (in the GFAK system).

Dipicolinic acid (DPA) and hexosamine release were measured by the methods of Scott \& Ellar (1978c) and Ghuysen et al. (1966) in exudates of spores germinated at $5 \mathrm{mg} \mathrm{ml}^{-1}$. In the ALA system, for DPA measurement, $50 \mathrm{mM}-\mathrm{KCl}$ buffer was used. Limited cortex hydrolysis was determined as previously described (Johnstone \& Ellar, 1982) in spores germinated at $5 \mathrm{mg} \mathrm{ml}^{-1}$. ATP synthesis was measured by the luciferin-luciferase chemiluminescence method (Scott \& Ellar, 1978c).

Loss of heat resistance was determined by heat-shocking samples of germinating spores at $70{ }^{\circ} \mathrm{C}$ for $30 \mathrm{~min}$ in distilled water (which killed $>99.99 \%$ of the germinated spore population), followed by serial dilution and plating on nutrient agar (Difco). Loss of heat resistance in the presence of $3 \mathrm{mM}-\mathrm{HgCl}_{2}$ in the ALA system was determined as described by Foster \& Johnstone (1986) except that the heat shock was carried out 90 min after addition of Lalanine.

Effects of $\mathrm{HgCl}_{2}$ on germination. The methods of Foster \& Johnstone (1986) were used, modified as follows.

(i) Overall inhibition. The overall effect of $\mathrm{HgCl}_{2}$ on both ALA- and GFAK-induced germination was determined by pre-treating spores $\left(0.05 \mathrm{mg} \mathrm{ml}^{-1}\right.$ in $50 \mathrm{mM}$-potassium phosphate buffer, $\mathrm{pH} 7.4$, or $50 \mathrm{~mm}$ Tris/ $\mathrm{HCl}$ buffer, $\mathrm{pH} 7 \cdot 5$, for the ALA and GFAK systems, respectively) with $\mathrm{HgCl}_{2}$ at $37^{\circ} \mathrm{C}$ for 15 min before addition of germinants; the percentage inhibition of $\mathrm{OD}_{600}$ loss was determined after 60 or 80 min, respectively, for the ALA and GFAK systems.

(ii) Effect on post-commitment $O D_{600}$ loss. Inhibition of post-commitment $\mathrm{OD}_{600}$ loss (site II) by $\mathrm{HgCl}_{2}$ in the ALA system was analysed as follows. Spores were germinated for $10 \mathrm{~min}$ at $0.05 \mathrm{mg} \mathrm{ml}^{-1}$ in the ALA system and commitment was halted by the addition of $10 \mathrm{mM}$ (final concentration) $\mathrm{D}$-alanine. $\mathrm{HgCl}_{2}$ was added 1 min later and the percentage inhibition determined from the subsequent $\mathrm{OD}_{600}$ loss compared to that observed in the control with no $\mathrm{HgCl}_{2}$ present. In the GFAK system, high concentrations of D-asparagine appear to protect postcommitment sensitive sites from the effects of $\mathrm{HgCl}_{2}$, and therefore D-asparagine cannot be used to stop commitment when analysing the post-commitment effects of $\mathrm{HgCl}_{2}$. The procedure was therefore modified as follows to test for the presence of a post-commitment $\mathrm{HgCl}_{2}$-sensitive site. Spores were germinated in GFAK at $0.5 \mathrm{mg} \mathrm{ml}^{-1}$ (at which concentration the rate of commitment is not significantly altered) for $10 \mathrm{~min}$ and centrifuged immediately $\left(12000 \mathrm{~g} ; 30 \mathrm{~s} ; 25^{\circ} \mathrm{C}\right)$ to remove the germinants. The pellets were resuspended in distilled water and added to cuvettes containing $\mathrm{HgCl}_{2}$ in $50 \mathrm{mM}$-Tris $/ \mathrm{HCl}$ buffer, $\mathrm{pH} 7 \cdot 5$, at $0.05 \mathrm{mg} \mathrm{ml}^{-1}$; the percentage inhibition of subsequent $\mathrm{OD}_{600}$ loss was determined as described above for the effect of $\mathrm{HgCl}_{2}$ on postcommitment $\mathrm{OD}_{600}$ loss. In control experiments, no further commitment was observed when resuspended spores were added to $50 \mathrm{~mm}$-Tris/ $\mathrm{HCl}$ buffer, $\mathrm{pH} 7 \cdot 5$.

In order to test reversibility of $\mathrm{ALA}$ site $\mathrm{II} \mathrm{HgCl}_{2}$ inhibition, spores were treated as above, $7 \mathrm{~mm}-\beta$ mercaptoethanol added (which caused maximal reversal) and the percentage inhibition of subsequent OD $_{600}$ loss determined as described for the effect of $\mathrm{HgCl}_{2}$ on post-commitment $\mathrm{OD}_{600}$ loss (above).

(iii) Effect on commitment. Inhibition of commitment by $\mathrm{HgCl}_{2}$ in the $\mathrm{ALA}$ system was analysed as follows. Since $\beta$-mercaptoethanol fully reverses post-commitment $\mathrm{HgCl}_{2}$-sensitive sites, the effect of $\mathrm{HgCl}_{2}$ on commitment can be determined by exposing spores to germinants for a fixed time period in the presence of $\mathrm{HgCl}_{2}$, followed by termination of commitment with D-alanine and subsequent exposure to $\beta$-mercaptoethanol (Foster $\&$ Johnstone, 1986). Spores were therefore pre-treated for $15 \mathrm{~min}$ with $\mathrm{HgCl}_{2}$ as described above for overall inhibition of germination by $\mathrm{HgCl}_{2}$, prior to the addition of $\mathrm{L}$-alanine and, after a further $90 \mathrm{~min}, 10 \mathrm{mM}$ (final concentration) D-alanine was added. One minute later, $7 \mathrm{~mm}-\beta$-mercaptoethanol was added and the percentage subsequent germination determined as described above for the effect of $\mathrm{HgCl}_{2}$ on post-commitment $\mathrm{OD}_{600}$ loss.

(iv) Protection of the asparagine receptor. The effects of D-asparagine and D-alanine in protecting the GFAK pathway from $\mathrm{HgCl}_{2}$ inhibition were analysed as follows. Ten-millilitre volumes of heat-activated spores at $0.05 \mathrm{mg} \mathrm{ml}^{-1}$ in Decon-washed Corex tubes were incubated for $5 \mathrm{~min}$ at $37^{\circ} \mathrm{C}$ in the presence of $10-300 \mathrm{mM}-\mathrm{D}$ asparagine or D-alanine. After addition of $1 \mathrm{mM}-\mathrm{HgCl}_{2}$, the spore suspensions were incubated for a further $15 \mathrm{~min}$ and washed three times by centrifugation $\left(5000 \mathrm{~g}, 5 \mathrm{~min}, 25^{\circ} \mathrm{C}\right)$ in $10 \mathrm{ml}$ distilled water, with the addition of the 
respective $\mathrm{D}$-amino acid to the first wash. Finally, the spores were resuspended in $20 \mu \mathrm{l}$ distilled water and added (final concentration $50 \mu \mathrm{g} \mathrm{ml}^{-1}$ ) to a cuvette containing GFK in Tris/HCl buffer. L-asparagine ( $30 \mathrm{~mm}$ ) was then added and the spores were germinated for $80 \mathrm{~min}$ as described above. Two controls, one untreated with $\mathrm{HgCl}_{2}$ and the other unprotected by the D-amino acid, were subjected to the same procedure.

Effects of other inhibitors on germination. The effects of proteases and other metabolic inhibitors on germination were studied using the following methods.

(i) Overall inhibition of germination. The overall effect of the other inhibitors used on ALA and GFAK systems was determined as described for $\mathrm{HgCl}_{2}$ overall inhibition (see above).

(ii) Effect on post-commitment. Spores were germinated for 10 or 15 min at $0.05 \mathrm{mg} \mathrm{ml}^{-1}$ or $0.5 \mathrm{mg} \mathrm{ml}^{-1}$ in ALA and GFAK respectively and the effect on post-commitment $\mathrm{OD}_{600}$ loss determined as for $\mathrm{HgCl}_{2}$ postcommitment inhibition (see above).

(iii) Effect on commitment. Spores $\left(0.05 \mathrm{mg} \mathrm{m}^{-1}\right)$ were pretreated with the inhibitor for $15 \mathrm{~min}$ as described for $\mathrm{HgCl}_{2}$ overall inhibition, prior to the addition of L-alanine or L-asparagine and, after a further $90 \mathrm{~min}, 10 \mathrm{mM}$ (final concentration) D-alanine was added to the ALA system. In both ALA and GFAK, the spores were centrifuged $\left(12000 \mathrm{~g} ; 30 \mathrm{~s} ; 25^{\circ} \mathrm{C}\right)$ and washed once in distilled water. The pellets were resuspended in distilled water and added to potassium phosphate buffer, $\mathrm{pH} 7 \cdot 4$, or Tris/ $\mathrm{HCl}, \mathrm{pH} 7.5$, and percentage inhibition of subsequent $\mathrm{OD}_{600}$ loss was determined after 60 or $80 \mathrm{~min}$, respectively, for the ALA and the GFAK system.

The overall effect of all the inhibitors used, apart from $\mathrm{HgCl}_{2}$ in the GFAK system, was reversible in both ALA and GFAK systems by washing in distilled water.

Reproducibility of results. All experiments were repeated at least twice and were internally consistent. Absolute germination rates and extents of germination varied by no more than $10 \%$ from day to day and between batches of spores.

Chemicals. Germinants and inhibitors were from Sigma, apart from $\mathrm{HgCl}_{2}$, which was from $\mathrm{BDH}$ and of AR grade.

\section{RESULTS}

Characterization of the $B$. subtilis 1604 spore germination response

In order to characterize the ALA and GFAK germination responses, the effects of time and temperature of the heat shock on germination rate were first established (Fig. 1). The germination rate increased in both ALA and GFAK with time of heat shock, as observed for $B$. megaterium KM (Johnstone et al., 1982). The conventional heat shock treatment of $1 \mathrm{~h}$ at $70^{\circ} \mathrm{C}$ does not achieve the maximal germination rate in either system. Although heat shock at $70{ }^{\circ} \mathrm{C}$ for $60 \mathrm{~min}$ is sub-optimal in this system, this treatment was routinely used since it has been employed in other germination studies of this organism (Sammons et al., 1981; Wax \& Freese, 1968). In addition, other effects such as release of spore components may occur during extended heat shock (Johnstone et al., 1982). The germination rate in GFAK was consistently five-tosixfold lower than that observed in ALA.

The optimum concentrations of germinants were also established. $K_{\mathrm{m}}$ values of $0.05 \mathrm{mM}$, $0.2 \mathrm{mM}, 0.9 \mathrm{mM}$ and $3.0 \mathrm{mM}$ were determined for L-alanine and the glucose, fructose and Lasparagine components of GFAK, respectively. In order to achieve optimal germination rates, the germinant concentration should be at least five times the $K_{\mathrm{m}}$. Thus germinant concentrations of $1 \mathrm{mM}$, and $5.6 \mathrm{mM}, 5.6 \mathrm{mM}$ and $30 \mathrm{~mm}$ were routinely used for L-alanine, and for the glucose, fructose and L-asparagine components of GFAK respectively. LineweaverBurk plots of germinant concentration against germination rate were linear for L-asparagine (Fig. 2), fructose and glucose (data not shown) over a wide concentration range. However, in the case of L-alanine, at low concentrations the germination rate was lower than expected (Fig. 2). This result may be interpreted as indicating that spores have other binding sites for L-alanine which compete with the germinant receptor for available L-alanine at low alanine concentrations.

\section{Sequence of biochemical events in ALA and GFAK pathways}

The biochemical events occurring in the ALA and GFAK pathways were next examined in order to determine their sequential interrelationships. The ability of spores of $B$. subtilis to become committed to germination was first measured by determining the percentage change in $\mathrm{OD}_{600}$ following dilution of germinating spore suspensions in high concentrations of $\mathrm{D}$-alanine 


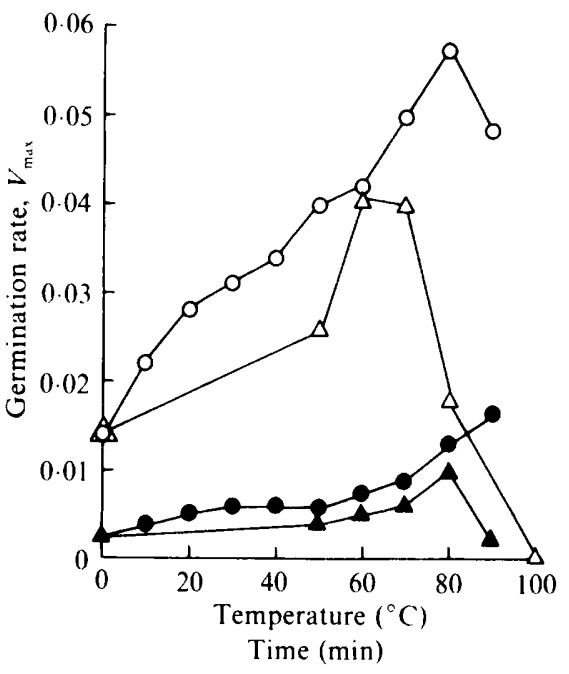

Fig. 1

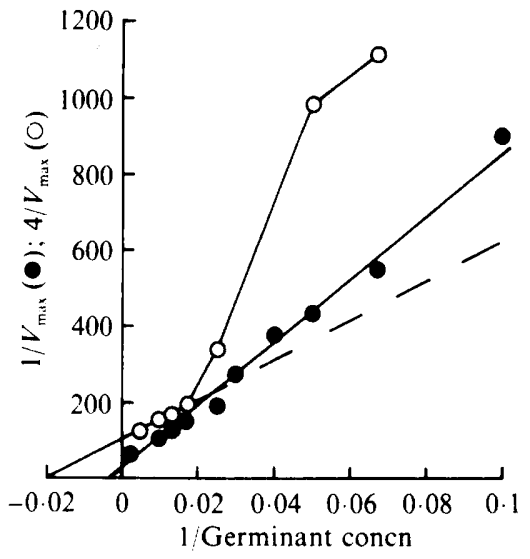

Fig. 2

Fig. 1. Effect of time and temperature of heat shock on germination rates of spores of $B$. subtilis in the ALA and GFAK systems. Spores were heat-shocked for $1 \mathrm{~h}$ at different temperatures $(\triangle, \Delta)$ or for varying times at $70^{\circ} \mathrm{C}(\mathrm{O}, \bigcirc)$ and germinated at $37^{\circ} \mathrm{C}$ at $50 \mu \mathrm{g} \mathrm{m} l^{-1}$ in the ALA $\left.\triangle, O\right)$ or GFAK $(\triangle, O)$ systems. The maximal rate of germination $\left(V_{\max }\right)$ was determined as described in Methods.

Fig. 2. Lineweaver-Burk plot of the effect of L-alanine and L-asparagine concentrations on the germination rate in the ALA and GFAK systems, respectively. Spores were germinated as described in Methods with varying concentrations of $\mathrm{L}$-alanine $(O, \mu \mathrm{M})$ and $\mathrm{L}$-asparagine $\left(O, \mu \mathrm{M} \times 10^{-1}\right)$ in the ALA and GFAK systems, respectively. The $V_{\max }$ for germination was determined as described in Methods and the $K_{\mathrm{m}}$ for each germinant calculated by extrapolation of the linear reciprocal plot, where the intersect on the abscissa equals $-1 / K_{\mathrm{m}}$ (Morris, 1968).

or D-asparagine (for the ALA and GFAK pathways, respectively) and incubation for the normal germination period. In both the ALA and GFAK pathways, commitment was observed and preceded $\mathrm{OD}_{600}$ loss (Fig. 3). Fifty percent commitment occurred after exposure of spores for $10 \mathrm{~min}$ and $14 \mathrm{~min}$ to ALA and GFAK, respectively, at which times $38 \%$ and $30 \%$ loss of $\mathrm{OD}_{600}$ respectively had taken place. In comparison, $50 \%$ commitment of $B$. megaterium $\mathrm{KM}$ spores occurs $4 \mathrm{~min}$ after exposure to germinant at $30^{\circ} \mathrm{C}$, at which time $<5 \% \mathrm{OD}_{600}$ loss has taken place (Stewart et al., 1981). This suggests either that commitment is more asynchronous in $B$. subtilis than in B. megaterium, or that commitment in $B$. subtilis is more closely associated with $\mathrm{OD}_{600}$ loss, and hence the relationship between these germination events differs from that in $B$. megaterium $\mathrm{KM}$.

The kinetics of loss of heat resistance, hexosamine release, DPA release, ATP synthesis and appearance of new cortical reducing groups were also determined in the ALA and GFAK pathways (Figs 3 and 4). In both pathways, loss of heat resistance was observed as an early event, which was closely followed by DPA release, $\mathrm{OD}_{600}$ loss and hexosamine release. When these results are compared with the kinetics of commitment and absorbance loss (Fig. 3), it is clear that commitment is the first-observed event in both germinant systems. On the basis of these kinetic data it is however extremely difficult to establish the inter-relationships between the other early germination events. The number of cortical reducing groups in residual peptidoglycan per mg of spores remained approximately constant in both ALA- and GFAKinduced germination of $B$. subtilis (Fig. 3). Since $10 \%\left[44 \mathrm{nmol}\right.$ hexosamine (mg spores) $\left.{ }^{-1}\right]$ and $22 \%$ [104 $\mathrm{nmol}$ hexosamine (mg spores) $\left.{ }^{-1}\right]$ of total spore hexosamine is released in ALA- and GFAK-induced germination, respectively, the ratio of cortical reducing groups to amount of remaining cortical hexosamine must therefore increase. Experiments are currently in progress to determine the identity of these new reducing groups in each germination pathway. 


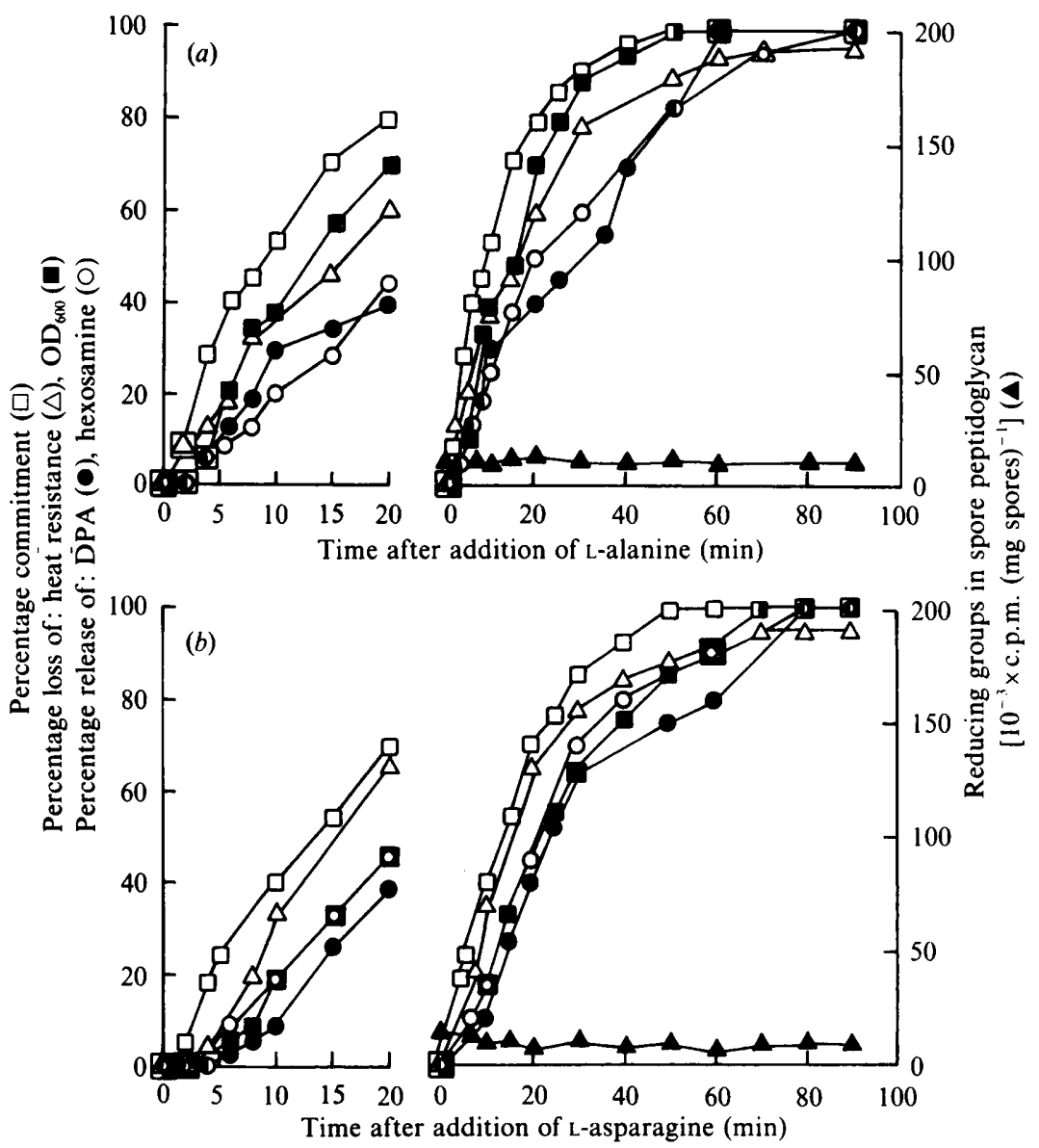

Fig. 3. Sequence of biochemical events during (a) ALA-induced and (b) GFAK-induced B. subtilis spore germination. Spores were germinated in ALA or GFAK and assays performed as described in Methods. $\square$, Percentage commitment; $\bullet$, percentage DPA release; $\boldsymbol{\square}$, percentage $\mathrm{OD}_{600}$ loss; $O$, percentage hexosamine release; $\Delta$, percentage loss of heat resistance; $\boldsymbol{\Delta}$, reducing groups in spore peptidoglycan measured by $\mathrm{NaBT}_{4}$ reduction and spore fractionation (Johnstone \& Ellar, 1982).

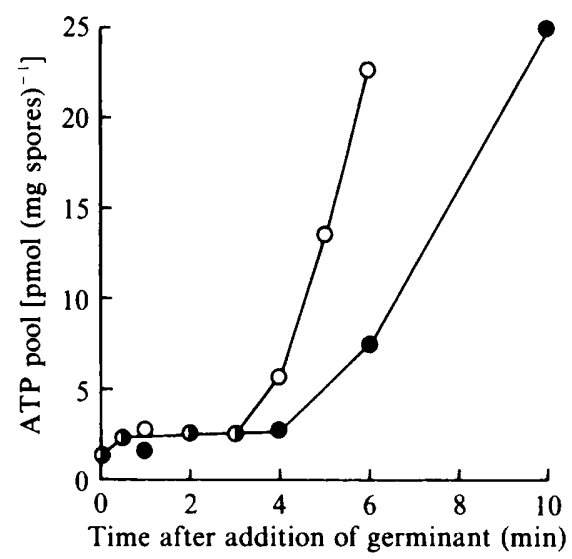

Fig. 4. ATP pool during $B$. subtilis spore germination. Spores were germinated in either the ALA (O) or GFAK (C) system and the ATP pool determined as described in Methods. 


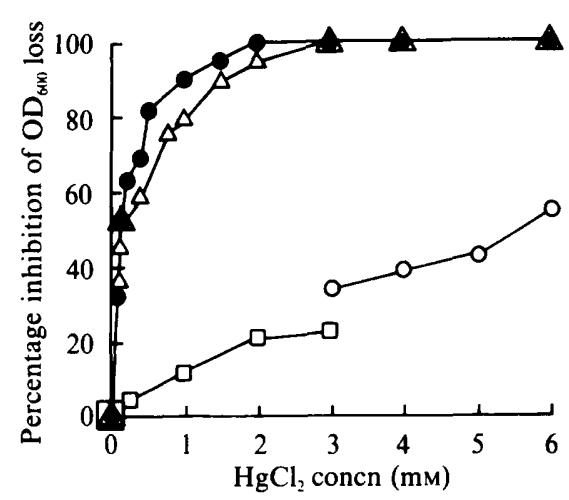

Fig. 5

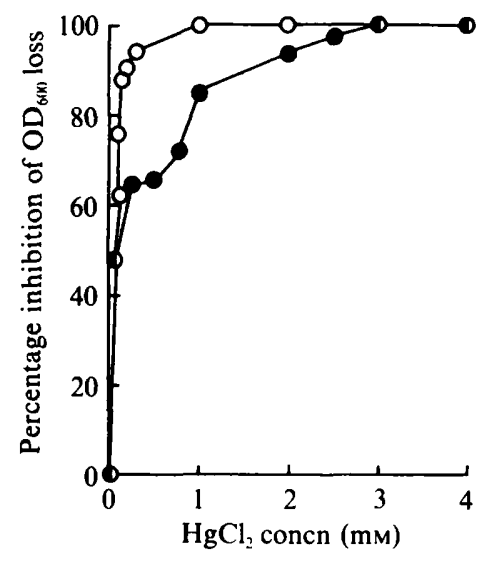

Fig. 6

Fig. 5. Effect of $\mathrm{HgCl}_{2}$ on the $B$. subtilis ALA germination response. $\triangle$, Overall effect of $\mathrm{HgCl}_{2}$ on germination - spores were pre-treated with $\mathrm{HgCl}_{2}$ and germinant-dependent $\mathrm{OD}_{600}$ loss was determined as described in Methods; - , effect of $\mathrm{HgCl}_{2}$ on post-commitment $\mathrm{OD}_{600}$ loss (site II) determined as described in Methods; $\square$, reversal of site II inhibition by 7 mM- $\beta$-mercaptoethanol spores were treated with $\mathrm{HgCl}_{2}$ followed by $7 \mathrm{mM}-\beta$-mercaptoethanol as described in Methods; $O$, effect of $\mathrm{HgCl}_{2}$ on commitment (site I) - spores were treated for $15 \mathrm{~min}$ with $\mathrm{HgCl}_{2}$ prior to the addition of $\mathrm{L}$-alanine and subsequent commitment was determined as in Methods.

Fig. 6. Effect of $\mathrm{HgCl}_{2}$ on the $B$. subtilis GFAK spore germination response. $O$, Overall effect of $\mathrm{HgCl}_{2}$ on germination - spores were treated with $\mathrm{HgCl}_{2}$ and germinant-dependent $\mathrm{OD}_{600}$ loss was determined as described in Methods; 0 , effect of $\mathrm{HgCl}_{2}$ on post-commitment $\mathrm{OD}_{600}$ loss (site II) as described in Methods.

ATP synthesis is a good indicator of initiation of general spore metabolism in B. megaterium KM (Johnstone et al., 1982). The time course of synthesis of ATP during triggering of B. subtilis spore germination was therefore examined. No detectable synthesis of ATP occurred in the ALA or GFAK systems until $3 \mathrm{~min}$ and $4 \mathrm{~min}$, respectively, after addition of germinants (Fig. 4). Since $20 \%$ of the spore population becomes committed to germinate at these times in both systems (Fig. 3), it is therefore concluded that net ATP synthesis is not required for germination triggering.

\section{Identification of $\mathrm{HgCl}_{2}$-sensitive sites during germination}

The germination inhibitor $\mathrm{HgCl}_{2}$ has been shown to be a valuable tool for dissection of the $B$. megaterium KM spore germination response (Foster \& Johnstone, 1986). The following experiments were carried out to determine whether the $B$. subtilis germination pathways could be analysed by similar techniques. Both the ALA and GFAK $B$. subtilis overall germination responses were inhibited by $\mathrm{HgCl}_{2}$ (Figs 5 and 6 ) and this inhibition could be $>95 \%$ reversed by the addition of a twofold molar excess of $\beta$-mercaptoethanol in the ALA system (results not shown). The overall inhibition of germination in the GFAK system by $\mathrm{HgCl}_{2}$ was considerably more sensitive than the ALA response: $1 \mathrm{mM}-\mathrm{HgCl}_{2}$ gave complete inhibition, and this inhibition could not be reversed either by washing or by $4 \mathrm{~mm}-\beta$-mercaptoethanol (results not shown). In contrast, the ALA response was fully inhibited only by $\geqslant 3 \mathrm{~mm}-\mathrm{HgCl}_{2}$. Postcommitment $\mathrm{HgCl}_{2}$-sensitve sites were examined in the ALA and GFAK pathways by determining the effect of $\mathrm{HgCl}_{2}$ on post-commitment $\mathrm{OD}_{600}$ loss (Foster \& Johnstone, 1986). The ALA post-commitment $\mathrm{HgCl}_{2}$-sensitive site appeared to be more sensitive than the overall germination response; it was $100 \%$ inhibited by $2 \mathrm{mM}-\mathrm{HgCl}_{2}$ and its inhibition could be $80 \%$ reversed by $7 \mathrm{~mm}-\beta$-mercaptoethanol (Fig. 5). An increase in sensitivity of the ALA postcommitment $\mathrm{HgCl}_{2}$-sensitive site during germination of $B$. megaterium $\mathbf{K M}$ spores has been previously noted (Foster \& Johnstone, 1986). The same phenomenon could also account for our observations. The GFAK post-commitment $\mathrm{HgCl}_{2}$ site differed from that in the ALA 


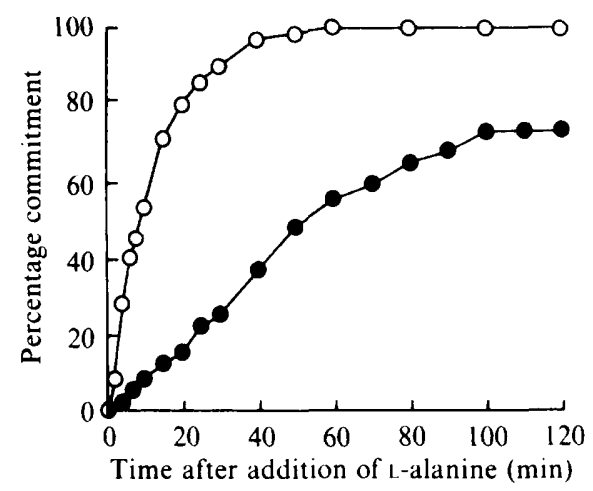

Fig. 7. Effect of $3 \mathrm{mM}-\mathrm{HgCl}_{2}$ on commitment of $B$. subtilis spore germination in the ALA system. $O$, Percentage commitment to germinate, determined as described in Methods; $O$, percentage commitment to germinate in the presence of $3 \mathrm{mM}-\mathrm{HgCl}_{2}$ determined, at the times indicated, as described in Fig. $5(\mathrm{O})$.

germinant system in that it was $50 \%$ inhibited by the presence of $0.005 \mathrm{mM}-\mathrm{HgCl}_{2}$ (Fig. 6) but $100 \%$ inhibition required $\mathrm{HgCl}_{2}$ concentrations $\geqslant 3 \mathrm{mM}$.

The presence of a post-commitment $\mathrm{HgCl}_{2}$-sensitive site in the ALA pathway allowed the presence of a pre-commitment site to be determined using existing methods (Foster \& Johnstone, 1986). Pre-commitment $\mathrm{HgCl}_{2}$ inhibition was less sensitive than the overall ALA response to $\mathrm{HgCl}_{2}$, being $55 \%$ inhibited by $6 \mathrm{mM}-\mathrm{HgCl}_{2}$ (Fig. 5). In the presence of $3 \mathrm{mM}-\mathrm{HgCl}_{2}$, $70 \%$ of the population became committed to germinate after $90 \mathrm{~min}$ (Fig. 7), whereas $<5 \%$ $\mathrm{OD}_{600}$ loss occurred after this time (Fig. 5). The rate of commitment in the presence of $3 \mathrm{mM}-$ $\mathrm{HgCl}_{2}$ was slower than that in the control (Fig. 7) and the maximal commitment was observed after $120 \mathrm{~min}$. Thus only commitment-associated events take place in the presence of $3 \mathrm{~mm}$ $\mathrm{HgCl}_{2}$ in the ALA germinant system. In the presence of $3 \mathrm{mM}-\mathrm{HgCl}_{2}, \mathrm{OD}_{600}$ loss and DPA release were $>90 \%$ inhibited by $3 \mathrm{mM}-\mathrm{HgCl}_{2}$ and therefore occur as post-commitment events. In contrast, $65-70 \%$ of the germinating spore population lost heat resistance after 90 min incubation in the presence of $3 \mathrm{mM}-\mathrm{HgCl}_{2}$ (results not shown). The creation of a heat-sensitive active enzyme may therefore constitute part of the ALA commitment reaction in B. subtilis, as observed for B. megaterium KM (Foster \& Johnstone, 1986). Since the overall inhibition of the GFAK pathway by $\mathrm{HgCl}_{2}$ could not be reversed by $\beta$-mercaptoethanol or by washing, these methods could not be employed to analyse loss of heat resistance in the GFAK pathway.

The B. subtilis ALA $\mathrm{HgCl}_{2}$-sensitive site(s) could not be tested for protection by D-alanine from the effects of $\mathrm{HgCl}_{2}$, since washing (as described in Methods) reversed the observed inhibition. The GFAK $\mathrm{HgCl}_{2}$-sensitive sites were $>90 \%$ inhibited by $1 \mathrm{mM}-\mathrm{HgCl}_{2}$ followed by washing and $30 \mathrm{mM}$-D-asparagine or $30 \mathrm{~mm}$-D-alanine protected these sites by $<5 \%$. These sites could however be fully protected by the presence of $300 \mathrm{~mm}$-D-asparagine during treatment with $1 \mathrm{mM}-\mathrm{HgCl}_{2}$; thus the asparagine-binding site may contain an $\mathrm{HgCl}_{2}$-sensitive $-\mathrm{SH}$ group.

\section{Effect of metabolic and protease inhibitors on germination}

Inhibitors have proved to be valuable tools in analysing the germination pathways of $B$. megaterium KM (Foster \& Johnstone, 1986) and B. cereus T (Boschwitz et al., 1985) and therefore the effects of a variety of inhibitors on the germination response of $B$. subtilis were studied. The presence of sodium arsenate $(1 \mathrm{mM})$ or potassium cyanide $(10 \mathrm{~mm})$ had no effect on ALA or GFAK responses. Although 10 mM-sodium azide had no effect on the ALA pathway, it inhibited the GFAK pathway by $92 \%$ as measured by $\mathrm{OD}_{600}$ loss, and this inhibition could be reversed by washing. Sodium azide $(10 \mathrm{~mm})$ inhibited the pre-commitment GFAK site by $>95 \%$ but had no effect on post-commitment $\mathrm{OD}_{600}$ loss. A variety of protease inhibitors had different effects on the ALA and GFAK pathways (Table 1). In common with spores of $B$. megaterium KM (Foster \& Johnstone, 1986) PMSF (3.33 mM) inhibited ALA germination, 
Table 1. Percentage inhibition by protease inhibitors of the B. subtilis spore germination response to $A L A$ and $G F A K$

The effects of protease inhibitors on the overall germination response, on pre-commitment reactions and on post-commitment reactions were determined as described in Methods.

\begin{tabular}{|c|c|c|c|c|c|c|}
\hline \multirow[b]{2}{*}{ Inhibitor* } & \multicolumn{3}{|c|}{ ALA } & \multicolumn{3}{|c|}{ GFAK } \\
\hline & $\begin{array}{c}\text { Overall } \\
\text { inhibition }\end{array}$ & $\begin{array}{c}\text { Pre- } \\
\text { commitment }\end{array}$ & $\begin{array}{c}\text { Post- } \\
\text { commitment }\end{array}$ & $\begin{array}{c}\text { Overall } \\
\text { inhibition }\end{array}$ & $\begin{array}{c}\text { Pre- } \\
\text { commitment }\end{array}$ & $\begin{array}{c}\text { Post- } \\
\text { commitment }\end{array}$ \\
\hline $\begin{array}{l}\text { PMSF } \\
(3.33 \mathrm{mM})\end{array}$ & 81 & $>95$ & $<10$ & 15 & ND & ND \\
\hline $\begin{array}{l}\text { TAME } \\
(50 \mathrm{mM})\end{array}$ & 97 & 97 & 89 & 92 & 90 & 80 \\
\hline $\begin{array}{l}\text { NEM } \\
(15 \mathrm{mM})\end{array}$ & 24 & ND & ND & 0 & ND & ND \\
\hline $\begin{array}{l}\text { TLCK } \\
(18 \mathrm{mM})\end{array}$ & 37 & ND & ND & 47 & ND & ND \\
\hline
\end{tabular}

acting at a pre-commitment site. The same concentration of PMSF had little effect on GFAK germination. Thus the ALA and GFAK pre-commitment reactions display different PMSFsensitive sites. In contrast, TAME inhibited both the ALA and GFAK pathways at both pre- and post-commitment sites (Table 1). These observations implicate the involvement of proteases in both germination pathways of $B$. subtilis.

\section{DISCUSSION}

Although metabolism of glucose by glucose dehydrogenase has been suggested to be part of the GFAK pathway (Prasad et al., 1972; Strauss, 1983), recent evidence has demonstrated that glucose dehydrogenase is not essential for this process (E. Freese, personal communication). Thus the germinants may have an allosteric rather than a metabolic role in triggering both germination pathways, as has been demonstrated for L-alanine-induced germination of $B$. megaterium KM (Scott \& Ellar, 1978a). This conclusion is supported by the observation that the non-metabolizable germinant analogue 2-deoxyglucose (Prasad et al., 1972) can be substituted for D-glucose in the GFAK system, and L-alanine chloromethylketone (P. Jayaraman, S. J. Foster \& K. Johnstone, unpublished) and cycloleucine (Woese, 1958; Sammons et al., 1981) can be substituted for L-alanine in the ALA system to allow triggering of germination. In addition, general spore metabolism, as reflected by net ATP synthesis, does not commence until after at least $20 \%$ of the spore population has become committed to germinate (Figs 3 and 4 ), and apart from sodium azide, the metabolic inhibitors tested had no effect on germination. In both the ALA and GFAK pathways of $B$. subtilis spore germination, commitment precedes all other germination events examined (Figs 3 and 4). The ALA and GFAK germinant receptors and trigger mechanisms are dissimilar in their affinity for germinants since the $K_{\mathrm{m}}$ values for individual components of the GFAK system are 4-60 times that observed for L-alanine. In contrast with spores of B. megaterium KM (Stewart et al., 1981), commitment to germination is closely followed by the loss of dormant spore properties. Thus, in both the ALA and GFAK pathways, the rate of subsequent germination events appears to be an important factor in determining the overall progress of germination.

Analysis of sequential events during germination of $B$. subtilis spores has revealed a similar pattern to that observed in other species of Bacillus (Foster \& Johnstone, 1986; Levinson \& Hyatt, 1966; Rossignol \& Vary, 1978). The $\mathrm{HgCl}_{2}$-sensitive sites previously observed in $B$. megaterium QMB 1551 (Levinson \& Hyatt, 1966; Rossignol \& Vary, 1978) have been used to dissociate the early germination events in $B$. subtilis. Loss of heat resistance was associated with 
commitment in the ALA germination system, while DPA release and loss of refractility were observed as post-commitment events in both the ALA and GFAK systems of $B$. subtilis. The results for the ALA pathway are similar to those observed for $B$. megaterium KM (Foster \& Johnstone, 1986). The closely associated DPA loss, release of soluble hexosamine fragments from the spore cortex and decrease in refractility observed in both the ALA and GFAK pathways (Fig. 3) are consistent with a model of spore germination in which selective cortex degradation of cortical peptidoglycan is responsible for irreversibly breaking spore dormancy (Foster \& Johnstone, 1986). In this model, depolymerization of the spore cortex allows core water uptake, and when the core water content reaches a critical level, general spore metabolism may commence. Although extensive cortex depolymerization could be detected as the release of peptidoglycan fragments in both the ALA and GFAK pathways, net production of cortical reducing groups was not detected in the residual spore cortex of spores germinated in either pathway. This suggests that the mechanism of cortex hydrolysis in $B$. subtilis differs from that of $B$. megaterium $\mathrm{KM}$ in which new muramic acid $\delta$-lactam residues are generated as an early germination event (Johnstone \& Ellar, 1982). Identification of the mechanism of cortex hydrolysis may allow it to be established whether the same cortex-lytic enzyme is activated in both the pathways.

Genetical analysis of $B$. subtilis spore germination has suggested that the ALA and GFAK pathways have some common steps (Piggot et al., 1981; Smith et al., 1977). The effects of inhibitors on these two responses have demonstrated that they differ in their pre-commitment inhibitor profiles. The concentrations of $\mathrm{HgCl}_{2}$ required for $50 \%$ inhibition of the ALA pre- and post-commitment sites are $5.5 \mathrm{mM}$ and $0.125 \mathrm{mM}$, respectively. In contrast, the concentration of $\mathrm{HgCl}_{2}$ required for inhibition of the GFAK pathway is less than that required to inhibit the post-commitment $\mathrm{HgCl}_{2}$-sensitive site (Fig. 6), which suggests that the pre-commitment site is sensitive to low concentrations of $\mathrm{HgCl}_{2}$. In addition, only the ALA pre-commitment event is PMSF sensitive, whereas both the ALA and GFAK pre- and post-commitment events are TAME sensitive. Thus the ALA and GFAK pathways have independent events. Although the mechanism whereby sodium azide inhibits pre-commitment events in the GFAK pathway remains to be established, its lack of effect on ALA germination is further evidence for functionally distinct germination triggering pathways.

We suggest that there are two ways in which these results for $B$. subtilis spore germination could be correlated with the model recently proposed for $B$. megaterium $\mathrm{KM}$ spore germination (Foster \& Johnstone, 1986). Firstly, B. subtilis may contain two independent pathways which activate separate cortex-lytic enzymes with different inhibitor profiles. These enzymes may hydrolyse the spore cortex by common or independent mechanisms and then converge at the point of cortex depolymerization. The different extent of cortex hydrolysis observed in the ALA and GFAK pathways would support this hypothesis. Alternatively, the commitment events in GFAK and ALA may result in activation of separate proteases, which activate a common cortex-lytic enzyme. The inhibitors TAME and $\mathrm{HgCl}_{2}$, which are known to inhibit proteases, have also been shown to inhibit the germination-specific cortex-lytic enzyme of $B$. megaterium (Foster \& Johnstone, 1987). In both cases, however, cortex hydrolysis would be a key germination event in regulating core rehydration (Foster \& Johnstone, 1987). It will therefore be necessary to isolate the enzyme(s) responsible for cortex degradation in the two germination pathways of $B$. subtilis in order to distinguish between these two possibilities.

We are grateful to Nehru Trust for Cambridge University for financial support (P. V.) and to Dr S. J. Foster for invaluable advice.

\section{REFERENCES}

Boschwitz, H., Halvorson, H. O., Keynan, A. \& MilneR, Y. (1985). Trypsin-like enzymes from dormant and germinated spores of Bacillus cereus $\mathrm{T}$ and their possible involvement in spore germination. Journal of Bacteriology 164, 302-309.

BRIGHT, J. J. \& JOHNSTONE, K. (1987). Germination kinetics of spores of Clostridium bifermentans M $86 \mathrm{~b}$. Microbios 52, 17-28.

Foster, S. J. \& Johnstone, K. (1986). The use of inhibitors to identify early events during Bacillus megaterium KM spore germination. Biochemical Journal 237, 865-870. 
Foster, S. J. \& JohnStone, K. (1987). Purification and properties of a germination-specific cortex-lytic enzyme from spores of Bacillus megaterium KM. Biochemical Journal 242, 573-579.

Foster, S. J. \& Johnstone, K. (1988). Germinationspecific cortex-lytic enzyme is activated during triggering of Bacillus megaterium KM spore germination. Molecular Microbiology 2, 727-733.

Ghuysen, J. M., Tipper, D. J. \& Strominger, J. L. (1966). Enzymes that degrade bacterial cell walls. Methods in Enzymology 8, 685-699.

GouLD, G. W. (1969). Germination. In The Bacterial Spore, pp. 397-444. Edited by G. W. Gould \& A. Hurst. London: Academic Press.

IRIE, R., OKamoto, T. \& Fujita, Y. (1982). A germination mutant of Bacillus subtilis deficient in response to glucose. Journal of General and Applied Microbiology 28, 345-354.

Johnstone, K. \& EllaR, D. J. (1982). The role of cortex hydrolysis in the triggering of germination of Bacillus megaterium KM endospores. Biochimica et biophysica acta 714, 185-191.

Johnstone, K., Stewart, G. S. A. B., SCotT, I. R. \& ELLAR, D. J. (1982). Zinc release and the sequence of events during triggering of Bacillus megaterium $\mathrm{KM}$ spore germination. Biochemical Journal 208, 407411.

Levinson, H. S. \& HyatT, M. T. (1966). Sequence of events during Bacillus megaterium spore germination. Journal of Bacteriology 91, 1811-1818.

MoIR, A. \& SMITH, D. A. (1985). The genetics of spore germination. In Fundamental and Applied Aspects of Bacterial Spores, pp. 89-100. Edited by G. J. Dring, D. J. Ellar \& G. W. Gould. London: Academic Press.

MoIr, A., Lafferty, E. \& SMIth, D. A. (1979). Genetic analysis of spore germination mutants of Bacillus subtilis 168: the correlation of phenotype with map location. Journal of General Microbiology 111, 165-180.

MorRIS, J. G. (1968). The kinetics of enzyme catalysed reactions. In $A$ Biologist's Physical Chemistry, pp. 278-321. London: Edward Arnold.

Piggot, P. J., MoIr, A. \& SMITH, D. A. (1981). Advances in the genetics of Bacillus subtilis differentiation. In Sporulation and Germination, pp. 29-39. Edited by H. S. Levinson, A. L. Sonenshein \& D. J. Tipper. Washington DC: American Society for Microbiology.

Prasad, C., Diesterhaft, M. \& Freese, E. (1972). Initiation of spore germination in glycolytic mutants of Bacillus subtilis. Journal of Bacteriology 110, 321328.

Rossignol, D. P. \& VARY, J. C. (1978). L-Proline initiated germination in Bacillus megaterium spores. In Spores VII, pp. 90-94. Edited by G. Chambliss \& J. C. Vary. Washington DC: American Society for Microbiology.

SAMmons, R. L., MoIR, A. \& SMith, D. A. (1981). Isolation and properties of spore germination mutants of Bacillus subtilis 168 deficient in the initiation of germination. Journal of General Microbiology 124, 229-241.

SCOTT, I. R. \& EllaR, D. J. (1978a). Metabolism and the triggering of germination of Bacillus megaterium: use of $L-\left[{ }^{3} \mathrm{H}\right]$ alanine and tritiated water to detect metabolism. Biochemical Journal 174, 635-640.

SCOTT, I. R. \& ElLAR, D. J. (1978b). Metabolism and the triggering of germination of Bacillus megaterium: concentrations of amino acids, organic acids, adenine nucleotides and nicotinamide nucleotides during germination. Biochemical Journal 174, 627-635.

ScOTT, I. R. \& EllaR, D. J. (1978c). Study of calcium dipicolinate release during bacterial spore germination by using a new, sensitive assay for dipicolinate. Journal of Bacteriology 135, 133-137.

SETLOW, P. (1981). Biochemistry of bacterial forespore development and germination. In Sporulation and Germination, pp. 13-28. Edited by H. L. Levinson, A.L. Sonenshein \& D. J. Tipper. Washington DC: American Society for Microbiology.

SMith, D. A., MoIR, A. \& LAFFERTY, E. (1977). Spore germination genetics in Bacillus subtilis. In Spore Research 1976, pp. 69-85. Edited by A. W. Barker, J. Wolf, D. J. Ellar, G. J. Dring \& G. W. Gould. London: Academic Press.

Stewart, G. S. A. B., Johnstone, K., Hagelberg, E. \& EllaR, D. J. (1981). Commitment of bacterial spores to germinate: a measure of the trigger reaction. Biochemical Journal 198, 101-106.

Strauss, N. (1983). Role of glucose dehydrogenase in germination of Bacillus subtilis spores. FEMS Microbiology Letters 20, 379-384.

WAX, R. \& FreEse, E. (1968). Initiation of the germination of Bacillus subtilis spores by a combination of compounds in place of L-alanine. Journal of Bacteriology 95, 433-438.

Woese, C. R., Morowitz, H. J. \& Hutchison, C. A. (1958). Analysis of action of L-alanine analogues in spore germination. Journal of Bacteriology 76, 578-588. 